\title{
THE MEDIAL MORAINES OF GHIACCIAIO DEI FORNI, VALTELLINA, ITALY: MORPHOLOGY AND SEDIMENTOLOGY
}

\author{
By C. SMiraglia
}

(Istituto di Geografia, Università Cattolica del Sacro Cuore, 20123 Milano, Italy)

ABSTRACT. Two distinct medial moraines are located on the tongue of Ghiacciaio dei Forni (Rhaetian Alps, Italy); they are formed by the confluence of three ice streams. The two ice-cored medial moraines originate from rock outcrops situated below the snow line. The moraines, which on the surface comprise angular clasts, extend for approximately $2 \mathrm{~km}$ and reach a maximum height of $10 \mathrm{~m}$. Nourishment of the moraines seems to be due primarily to the supraglacial debris derived from the rock walls. Measurements made in the late summer of 1985 provided evidence of the role played by differential ablation in the development of these moraines. Sedimentological analysis further confirmed the mainly supraglacial origin of the debris comprising the moraines.

\section{INTRODUCTION}

Medial moraines are one of the most distinctive features of the surface morphology of glaciers and they have been widely studied. Models of their formation and evolution have been derived (Small and Clark, 1974; Eyles and Rogerson, 1978a, b; Boulton and Eyles, 1979; Small and others, 1979; Gomez and Small, 1985). As far as the Italian Alps are concerned, interest in epiglacial morphology is very recent. The preliminary results of the first research conducted on the medial moraines of a glacier in Italy are presented in this paper. Ghiacciaio dei Forni, the largest glacier $\left(13 \mathrm{~km}^{2}\right)$ in this Alpine sector, is located in Upper Valtellina (Lombardy). It is a composite valley glacier, formed by three ice streams, the confluence of which forms a tongue that extends over $2 \mathrm{~km}$ (Fig. 1).

In the summers of 1985 and 1987, transverse and longitudinal sections were measured on the medial moraines of this glacier using topographical surveys. Differential ablation was calculated according to methods used by previous researchers (specifically Small and Clark, 1974) and samples were collected for grain-size analysis.

\section{THE MORPHOLOGY AND DEVELOPMENT OF THE} MEDIAL MORAINES

Two principal medial moraines can be distinguished on the tongue of Ghiacciaio dei Forni. The eastern moraine is $1.8 \mathrm{~km}$ long and originates at $2710 \mathrm{~m}$ at the base of a rocky spur, the peak of which reaches $3226 \mathrm{~m}$. On the whole, the moraine has a crest-shaped form with a surface layer of coarse and angular debris (the thickness of which varies on average from 5 to $20 \mathrm{~cm}$, excluding the larger boulders) covering the ice. The morainic ridge trends north-west. Intersected by numerous transverse crevasses, it tends to become increasingly higher and wider in a fairly regular manner. Its maximum height $(10-12 \mathrm{~m})$ occurs over a distance of $450 \mathrm{~m}$ at an altitude of $2670 \mathrm{~m}$. In this sector, the maximum inclination of the slopes has also been recorded $\left(25-26^{\circ}\right)$. The moraine then extends in a northnorth-west direction and continues to widen. Its slope, however, decreases until it is barely discernible. The ridge transforms into a wide fan $(200 \mathrm{~m}$ in width) composed of scattered material. This is an area exhibiting extreme

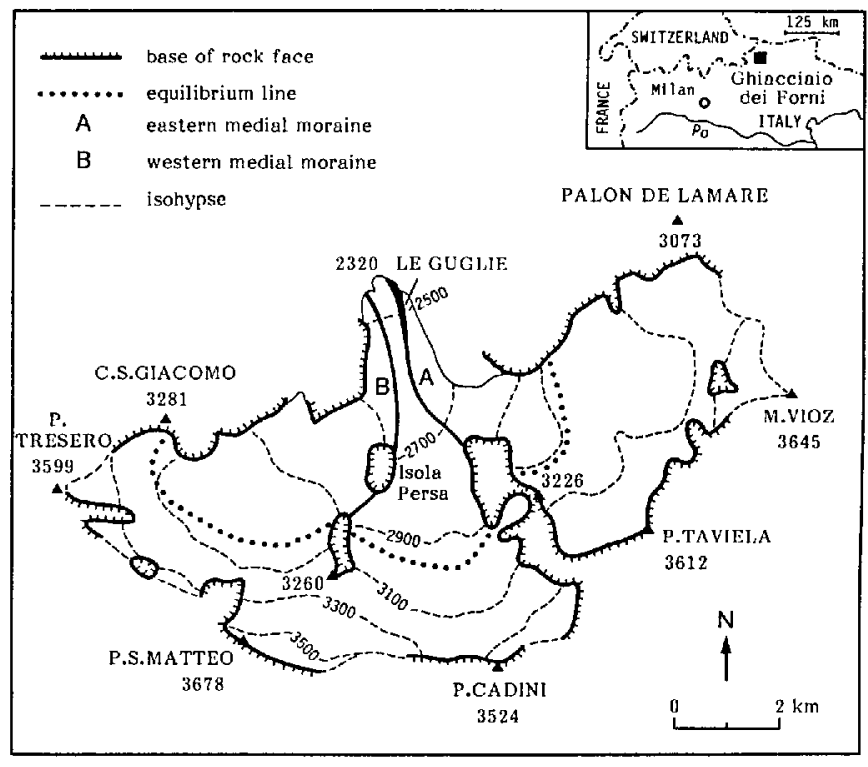

Fig. 1. Ghiacciaio dei Forni.

fragmentation of the glacier surface and where the intersection of the transverse and oblique crevasses forms an ice fall, locally known as "Le Guglie" (The Needles or Les Aiguilles).

The western medial moraine has a morphology that is decidely more irregular. Its upper part originates from a spur at a height of $3260-2897 \mathrm{~m}$, extends in a narrow form, and is only slightly noticeable up to a rock outcrop. The latter is almost completely covered by debris and is called "Isola Persa" or Lost Island $(2742 \mathrm{~m})$. The moraine extends below "Isola Persa" northward to a height of $2600 \mathrm{~m}$. It is intersected by numerous transverse crevasses. Below $2600 \mathrm{~m}$, the debris cover is distributed in a north-west direction over a larger surface area. The total length of the moraine is approximately $2 \mathrm{~km}$. The greatest heights $(8 \rightarrow 9 \mathrm{~m})$ of the moraine occur slightly below "Isola Persa", corresponding to the greatest width $(35 \mathrm{~m})$ and the greatest inclination of the slopes $\left(33^{\circ}\right)$. The morphometric characteristics of both moraines are briefly outlined in Table I and Figure 2.

The various processes determining the origin and the development of medial moraines have already been indicated by some of the researchers mentioned above (for example, see the models proposed by Small and Clark, 1976; Eyles and Rogerson, 1978a; Gomez and Small, 1985). These researchers have stressed the complex relations between debris supply, lateral compression of the ice streams, and differential ablation. With regard to the latter, measurements of ablation relating to the thickness of the debris cover on the medial moraines of Ghiacciaio dei Forni were carried out in September 1985. After 2 weeks, it was observed that eight ablation stakes driven into the bare ice had registered a mean diurnal ablation of $2.8 \mathrm{~cm}$ with values ranging from 2.6 to $3.5 \mathrm{~cm}$. 
TABLE I. MORPHOLOGY OF THE MEDIAL MORAINES, GHIACCIAIO DEI FORNI

\begin{tabular}{|c|c|c|c|c|}
\hline Section & $\begin{array}{l}\text { Distance from } \\
\text { starting } \\
\text { point }\end{array}$ & $\begin{array}{l}\text { Maximum } \\
\text { height }\end{array}$ & $\begin{array}{l}\text { Maximum } \\
\text { width }\end{array}$ & $\begin{array}{l}\text { Maximum } \\
\text { slope }\end{array}$ \\
\hline & $\mathrm{m}$ & $\mathbf{m}$ & $\mathrm{m}$ & deg \\
\hline
\end{tabular}

A. Eastern moraine

$\begin{array}{lr}\text { A } & 20 \\ \text { B } & 265 \\ \text { C } & 450 \\ \text { D } & 760 \\ \text { E } & 980\end{array}$

$\begin{array}{ll}2 & 11 \\ 5.5 & 24 \\ 9.5 & 30 \\ 10 & 47 \\ 2.5 & 50\end{array}$

18
23
26
15
4

B. Western moraine

$\begin{array}{lr}\text { A } & 375 \\ \text { B } & 645 \\ \text { C } & 775 \\ \text { D } & 950 \\ \text { E } & 1125\end{array}$

$\begin{array}{ll}2 & 7 \\ 9 & 35 \\ 3 & 10 \\ 1.5 & 15 \\ 4 & 17\end{array}$

125

\section{EASTERN MORAINE} (A) $\mathrm{SW} \stackrel{18}{18} \stackrel{17}{\mathrm{NE}}$

(B)

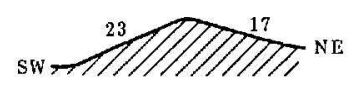

(C)

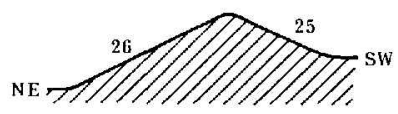

(D)

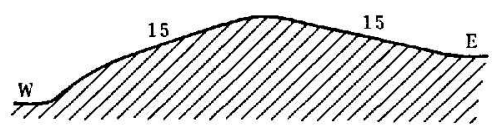

(e)

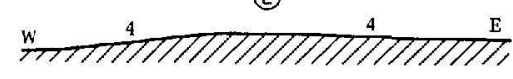

$\underbrace{0 . \quad r^{10} \mathrm{~m}}$

Fig. 2. Cross-profiles of the medial moraines of Ghiacciaio dei Forni. The numbers indicate slopes in degrees.

With $1-2 \mathrm{~cm}$ of silt and sand cover, there was a surface lowering of $3.3 \mathrm{~cm}(118 \%$ of the ablation observed on the bare ice). On the other hand, with a protective debris layer more than $2 \mathrm{~cm}$ thick, ablation was retarded. With $4 \mathrm{~cm}$ of debris, there was in fact a reduction in the ablation rate to $2.3 \mathrm{~cm}$ (that is, $82.1 \%$ of the bare-ice value), and with $6 \mathrm{~cm}$ the reduction was down to $2.1 \mathrm{~cm} / \mathrm{d}$ (75\%).

Regarding the source of the debris comprising the surface layer of the medial moraines, at the end of the summers of 1986 and 1987 , when the snow line was situated around $2900-3000 \mathrm{~m}$, it was possible to distinguish clearly the contact between the medial moraines and the rock walls. Direct nourishment of the moraines by debris derived from the rock walls was evident. The rock walls are formed of highly fractured phyllites and are subject to intense frost-shattering, which causes frequent rock falls. The debris is distributed over. the surface of the glacier, forming a discontinuous cover at the base of the walls, up to a height of $2710 \mathrm{~m}$ in the case of the eastern moraine and $2990 \mathrm{~m}$ for the western moraine. The possiblity cannot be excluded that a certain amount of englacial or subglacial debris, derived from material that entered the crevasses and from basal erosion, may contribute to the debris supply of

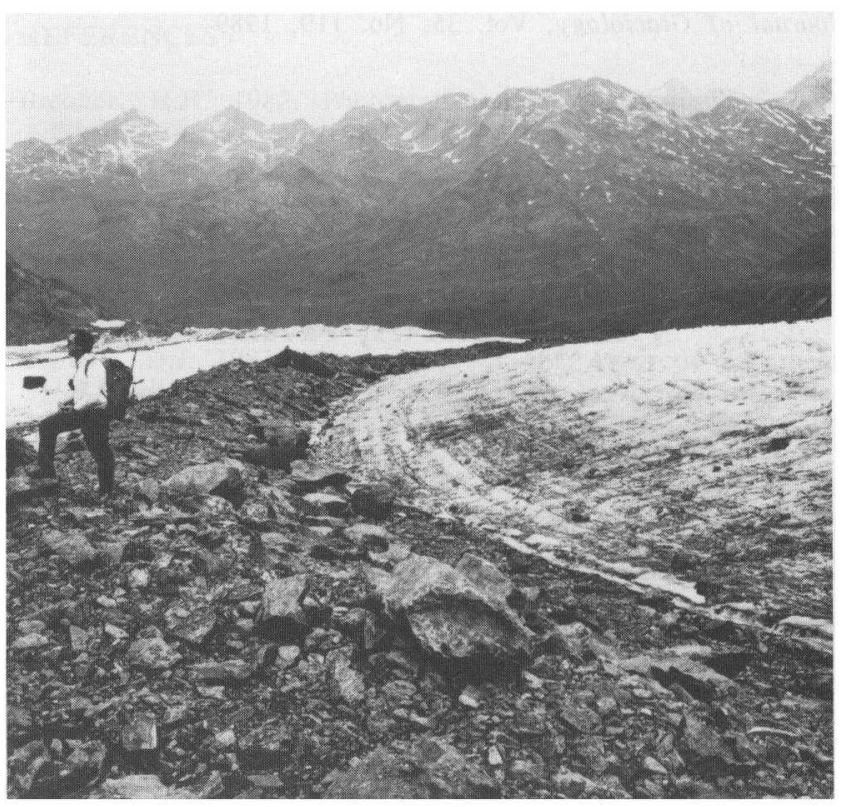

Fig. 3. Detail of the eastern medial moraine. Note the predominant coarse and angular material that comprises the surface debris laver.

the moraines. However, no evidence such as the nearly vertical englacial debris bands, like those cited by Gomez and Small (1985) for Haut Glacier d'Arolla, has been found on Ghiacciaio dei Forni.

Further development of the medial moraines on Ghiacciaio dei Forni may be briefly summarized as follows:

(1) Due to interaction between the ice streams, and to lateral compression in particular, the debris takes on a longitudinal septum form. In the case of the eastern moraine, this is already observable at $100 \mathrm{~m}$ below the rock spur at $3226 \mathrm{~m}$ altitude.

(2) Differential ablation is beginning to take effect (Da > 1).* The debris cover, which consists of rock fragments and which has a thickness that on average is greater than $2-3 \mathrm{~cm}$, protects the ice directly beneath it from melting. At the same time, ablation is able to operate normally on the bare ice around it.

(3) The morainic ridge height increases with respect to the level of the surrounding ice, until reaching the maximum height and the maximum inclination of the slopes. This is the so-called waxing section, the lower boundary of which for the eastern moraine of Ghiacciaio dei Forni can be located at a height of $2660 \mathrm{~m}$ and at about $750 \mathrm{~m}$ from its origin, where the height of the moraine itself is $10 \mathrm{~m}$.

(4) Beyond the critical point of lateral slope inclination (which is estimated around $35^{\circ}$ for both moraines), the rock fragments tend to slide down the sides. The protective cover diminishes in thickness (on average it is less than $2 \mathrm{~cm}$ ); thus $\mathrm{Da}<1$ and numerous sites of ice remain bare.

(5) The lack of protection of the bare areas and heat transmission to the underlying ice over that part of the thin layer of residual debris cause the reduction in the moraine's height (this is the so-called waning section). The moraine is reduced to a wide yet thin veneer of superficial material. This phenomenon is quite visible in the case of the eastern moraine, which in its terminal area takes on a typical fan shape with its apex pointing up-glacier and then deviates north-north-eastward down to $2450 \mathrm{~m}$.

From the above observations and bearing in mind that (i) debris supply seems to be predominantly superficial, that (ii) the source of this supply is for the most part situated below the snow line, and that (iii) it is possible to distinguish a waxing section and a waning section, it is possible to conclude that the medial moraines of Ghiacciaio

${ }^{*} \mathrm{Da}$ is the ratio between ablation of bare ice and ablation of debris-covered ice (Small and Clark, 1976). 
dei Forni can be included in the type A category in the classification system proposed by Small and others (1979). Moreover, taking into account the models of formation identified by Eyles and Rogerson (1978a), these moraines may be defined as ice-stream interaction (ISI) moraines.

\section{SEDIMENTOLOGY}

A grain-size analysis was carried out in order to obtain further information on the characteristics and the origin of the debris in the medial moraines of Ghiacciaio dei Forni. Some samples were collected on the eastern medial moraine at a height of $2680 \mathrm{~m}$ and approximately $700 \mathrm{~m}$ from the base of the rock spur $3226 \mathrm{~m}$. For comparison, samples of subglacial sediment were also collected on the right-hand side of the terminal sector of the tongue at the ice-rock interface. These samples were analysed in the Sedimentology Laboratory of the Department of Earth Sciences at the University of Milan. Standard sieving methods were used for fractions up to sand particles (4 ф). Aerometry was used for the finer fractions. Mean size, standard deviation, skewness, and kurtosis were calculated by a graphical method.

Sediment from the eastern medial moraine can be classified as mainly pebbly and sandy; 59 and $37.5 \%$ of the weight of the samples collected are concentrated in the -4 to $-1 \phi$ fraction and in the -1 to $4 \phi$ fraction, respectively. Mean size varies from granule to coarse sand. The debris samples can be defined as poorly sorted to very poorly sorted (standard deviation varies between 1.25 and $2.50 \Phi$ ).

By contrast, the subglacial debris is mainly silty and clayey ( $55.7 \%$ silt, $24.9 \%$ clay) and to a lesser extent, sandy. Mean size falls within the silt fraction. The differences between the medial moraine sediment and the subglacial sediment are shown in Figures 4 and 5.

Grain-size distributions for debris from the medial moraine (a) and the subglacial deposits (b) are shown in Figure 4. Graph (a) highlights the predominantly coarse nature of the material (the mode ranges between -2 and $0 \phi)$ and the relative lack of fine sand and silt. The curve appears to be similar to that shown by Boulton (1978) for the supraglacial debris of Glacier d'Argentière. In graph (b) the grain-size distribution shows a very distinct mode between 4 and $6 \phi$, thus with a predominance of fine material.

Mean sizes and respective standard deviations are compared in Figure 5. With respect to the medial moraine debris, the subglacial debris has a smaller mean size, a greater standard deviation, and also a lower value of skewness. These are all elements that should characterize debris derived by erosion at the ice-rock contact ("basal zone of traction"; Boulton, 1978).
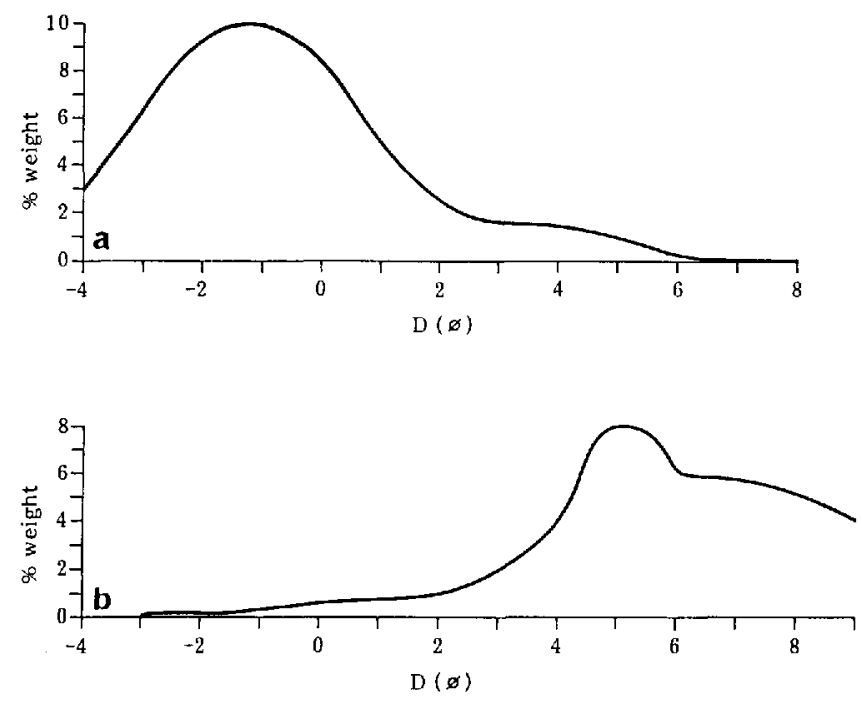

Fig. 4. Grain-size distribution (mean values) of sediment from the eastern medial moraine (a) and of the subglacial sediment (b).

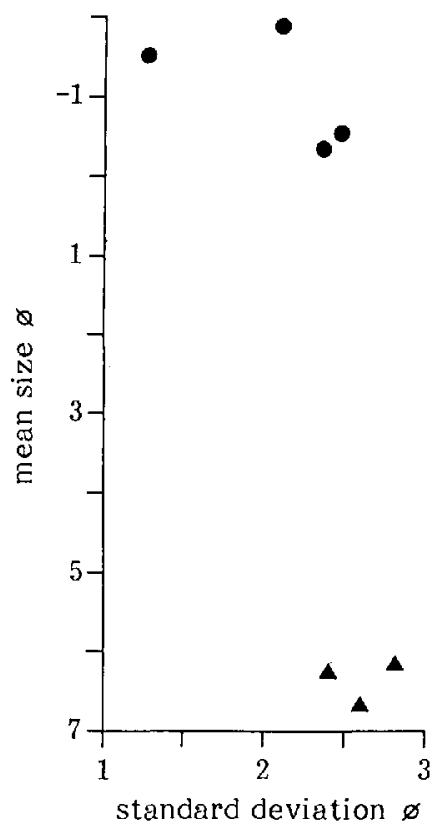

Fig. 5. Relations between standard deviation and mean size for sediment from the eastern medial moraine (solid circles) and for the subglacial deposits (solid triangles).

Though admittedly carried out on a limited number of samples, the grain-size analysis did show a clear distinction between the subglacial debris and that from the medial moraines of Ghiacciaio dei Forni.

The latter are basically of a larger mean size, which indicates limited fragmentation and transport that was virtually passive. The sediment from the medial moraines of Ghiacciaio dei Forni therefore shows a predominantly "supraglacial nature", to use Small's (1983) expression, which is typical of debris that has been transported "at a high level" (Boulton, 1978). In conclusion, these results lend further support to the hypothesis of a predominantly superficial origin for the deposits that comprise the media moraines of Ghiacciaio dei Forni.

\section{ACKNOWLEDGEMENTS}

This study, which is part of a research programme co-ordinated by the Comitato Glaciologico Italiano (Italian Glaciological Committee) and the Glaciological Section of the National Physical Geography and Geomorphology Group of the CNR (Italian National Research Council), was carried out with the financial support $(60 \%$ contribution) of the Ministry of Education and the CNR (850089705, Director G.B. Castiglioni). Dr G. Catasta assisted with the field work. The author also wishes to thank Professor G. Orombelli for his advice and critical comments on the text, as well as the Director of the National Park of Stelvio for his valuable assistance.

\section{REFERENCES}

Boulton, G.S. 1978. Boulder shapes and grain size distribution as indicators of transport paths through a glacier and till genesis. Sedimentology, 25(6), 773-779.

Boulton, G.S. and N. Eyles. 1979. Sedimentation by valley glaciers; a model and genetic classification. In Schlüchter, C., ed. Moraines and varves: origin, genesis, classification. Proceedings of an INQUA Symposium on Genesis and Lithology of Quaternary Deposits, Zürich, 10-20 September 1978. Rotterdam, A.A. Balkema, 11-23.

Eyles, N. and R.J. Rogerson. 1978a. A framework for the investigation of medial moraine formation: Austerdalsbreen, Norway, and Berendon Glacier, British Columbia, Canada. J. Glaciol., 20(82), 99-113.

Eyles, N. and R.J. Rogerson. 1978b. Sedimentology of medial moraines on Berendon Glacier, British Columbia 
Canada: implications for debris transport in a glacierized basin. Geol. Soc. Am. Bull., 89(11), 1688-1693.

Gomez, B. and R.J. Small. 1985. Medial moraines of the Haut Glacier d'Arolla, Valais, Switzerland: debris supply and implications for moraine formation. $J$. Glaciol., 31(109), 303-307.

Small, R.J. 1983. Lateral moraines of Glacier de Tsidjiore Nouve: form, development, and implications. J. Glaciol., 29(102), 250-259.
Small, R.J. and M.J. Clark. 1974. The medial moraines of the lower Glacier de Tsidjiore Nouve, Valais, Switzerland. J. Glaciol., 13(68), 255-263.

Small, R.J. and M.J. Clark. 1976. Morphology and development of medial moraines: reply to comments by N. Eyles. J. Glaciol., 17(75), 162-164.

Small, R.J., M.J. Clark, and T.J.P. Cawse. 1979. The formation of medial moraines on Alpine glaciers. $J$. Glaciol., 22(86), 43-52.

MS. received 30 June 1988 and in revised form 3 December 1988 